\title{
KORELASI PENGGUNAAN STRATEGI MEMBACA SELEKTIF TERHADAP KEMAMPUAN MEMBACA PEMAHAMAN TEKS PENDEK DOKKA/ (Penelitian Deskriptif Pada Mahasiswa Tingkat II Tahun Ajaran 2014/2015)
}

\author{
Adhistiara Amalia Ananda \\ Drs.Ahmad Dahidi, M.A.,' \\ Juju Juangsih,M.Pd. ${ }^{2}$ \\ Departemen Pendidikan Bahasa Jepang \\ Fakultas Pendidikan Bahasa dan Sastra \\ Universitas Pendidikan Indonesia \\ Ayaryu707@yahoo.com
}

\begin{abstract}
ABSTRAK
Sebagai pembelajar bahasa Jepang, membaca artikel dalam bahasa Jepang sangat diperlukan, membaca artikel bahasa Jepang selain meningkatkan wawasan tentang perkembangan kehidupan negara Jepang dalam segala bidang, juga dapat meningkatkan kemampuan berbahasa seseorang. Dalam pembelajaran bahasa Jepang terdapat beberapa keterampilan yang dipelajari, salah satunya adalah dokkai. Dokkai adalah keterampilan memahami teks dalam waktu singkat. Untuk dapat memahami teks dalam waktu singkat dibutuhkan usaha dan langkah-langkah strategis. Tujuan dari penelitian ini adalah untuk mendeskripsikan hubungan antara strategi membaca dengan pemahaman membaca teks dokkai dengan menggunakan metode deskriptif pendekatan kuantitatif. Pengumpulan data pada penelitian ini menggunakan 2 jenis instrumen, yaitu tes tertulis dan angket yang dilakukan pada 20 responden. Dari penelitian tersebut, diperoleh hasil nilai koefisien korelasi sebesar 0,91 yang menunjukan bahwa terdapat hubungan yang sigifikan antara penggunaan strategi membaca selektif dengan kemampuan pemahaman membaca teks dokkai dan sebesar $82 \%$ tingkat pemahaman membaca teks dokkai dipengaruhi oleh strategi membaca dan $18 \%$ oleh faktor lain. Oleh karena itu hipotesis dari penelitian ini diterima bahwa penggunaan strategi membaca memiliki hubungan positif terhadap prestasi pemahaman membaca mahasiswa tingkat II Departemen Pendidikan Bahasa Jepang tahun ajaran 2014/2015.
\end{abstract}

Keyword: Strategi membaca selektif, membaca pemahaman, korelasi

\footnotetext{
${ }^{1}$ Penanggung Jawab 1

${ }^{2}$ Penanggung Jawab 2
} 


\title{
CORELATION BETWEEN READING SELECTIVE STRATEGIES WITH READING COMPREHENSION TEXT JAPANESE SKILL (Descriptive Method On Student Level II Departement of Japanese Language, Indonesia University of Education, Academic Year 2014/2015)
}

\author{
Adhistiara Amalia Ananda \\ Drs.Ahmad Dahidi, M.A.,' \\ Juju Juangsih,M.Pd. ${ }^{2}$ \\ Departemen Pendidikan Bahasa Jepang \\ Fakultas Pendidikan Bahasa dan Sastra \\ Universitas Pendidikan Indonesia \\ Ayaryu707@yahoo.com
}

\begin{abstract}
As a student of the Japanese language, reading the Japanese article is necessary, read the Japanese article beside to increase knowledge about the development of the life of Japanese nationals in all fields, can also increase a someone's language ability. In the Japanese language learning skills learned there are several, one of which is dokkai. Dokkai is a skill to understand the text in a short time. To be able to understand the text in the short time it takes effort and strategic measures. This research was conduted to know is there a significant relationship between reading comprehension text Japanese skill and reading selective stretegies. This research used descriptive method. This research used two kinds of instrument to assemble data, which were questionnaire and test. The data were taken by regration and colleration technique, which was taking data at once in the same time. The participants of the research were 20 students of Japanese Language Departement Indonesia University of Education. From the result, it was found that the correlation coefficient 0,91 which is significant relationship between reading comprehension text Japanese skill and reading selective stretegies and 82\% level reading comprehension influenced by selective reading strategies and $18 \%$ of another factors. Therefore, hypothesized in this research is recived that used reading selective have a positive relationship with reading comprehension text Japanese skill in 2 level student of Departement of Japanese Language, Indonesia of Education University in academic year 2014/2015.
\end{abstract}

Keyword : corelation between reading selective strategies, reading comprehension, correlation

\footnotetext{
${ }^{1}$ Penanggung Jawab 1

${ }^{2}$ Penanggung Jawab 2
} 


\section{PENDAHULUAN}

Dalam pembelajaran bahasa Jepang terdapat beberapa keterampilan yang dipelajari. Misalnya, keterampilan membaca (dokkai), mendengar (choukai), berbicara (kaiwa), menulis (sakubun). Beberapa keterampilan tersebut merupakan kompetensi yang harus dikuasai oleh pembelajar bahasa Jepang tingkat dasar maupun tingkat lanjutan. Sebagai pembelajar bahasa Jepang, membaca artikel dalam bahasa Jepang sangat diperlukan, membaca artikel bahasa Jepang selain meningkatkan wawasan tentang perkembangan kehidupan negara Jepang dalam segala bidang, juga dapat meningkatkan kemampuan berbahasa seseorang. Banyak pembelajar yang tidak mampu memahami apa yang di baca atau disimak dalam keterampilan membaca (dokkai). Hal ini juga sering terjadi pada mata kuliah Dokkai. Ketidakmampuan ini dapat disebabkan oleh berbagai faktor, misalnya, untuk dapat memahami isi bacaan yang disimak pembelajar harus mengetahui tema yang akan dipahaminya. Paling tidak pembelajar harus memiliki pengetahuan awal tentang tema atau konsep dari bacaan tersebut.

(Brown, 2001). Strategi membaca adalah cara atau langkah yang digunakan oleh para siswa untuk meningkatkan kemampuan pemahaman membaca. Pada dasarnya, strategi membaca menggambarkan bagaimana pembaca memproses bacaan sehingga pembaca memperoleh pemahaman terhadap bacaan tersebut. Tujuan dilakukannya penelitian ini adalah untuk mengetahui gambaran umum penggunaan strategi membaca dan kemampuan membaca pemahaman teks pendek dokkai oleh mahasiswa, khususnya strategi membaca selektif, untuk mengetahui kemampuan pemahaman membaca teks pendek dokkai mahasiswa tingkat II kelas 3A Departemen Pendidikan Bahasa Jepang, untuk mengetahui hubungan antara penggunaan strategi membaca selektif dengan pemahaman membaca teks pendek dokkai.

\section{METODE PENELITIAN}

Penelitian ini merupakan penelitian korelasi yang bertujuan untuk mengetahui ada tidaknya hubungan antara dua variabel atau lebih, mengetahui besarnya hubungan antar variebel-variabel tersebut dan untuk mengetahui berarti tidaknya hubungan tersebut jika digeneralisasikan pada populasi lain. Metode yang digunakan dalam penelitian ini adalah metode deskriptif dengan pendekatan kuantitatif serta dengan teknik korelasi, yakni mendeskripsikan hubungan penggunaan strategi membaca selektif terhadap kemampuan pemahaman membaca teks pendek dokkai. Sebagaimana yang dikemukakan oleh Sutedi (2011: 58) bahwa penelitian deskriptif yaitu penelitian yang dilakukan untuk menggambarkan, menjabarkan suatu fenomena yang terjadi saat ini dengan menggunakan prosedur ilmiah untukmenjawab masalah secara aktual.

Populasi dalam penelitian ini adalah mahasiswa tingkat II Departemen pendidikan Bahasa jepang FPBS UPI tahun ajaran 2014-2015. Sampel yang di 
ambil dalam penelitian ini adalah mahasiswa pendidikan Bahasa Jepang tingkat II kelas 3A yang berjumlah 20 orang. Dalam penelitian ini data diambil dari kedua instrumen penelitian yaitu tes dan non tes. Untuk instrumen penelitian berupa tes, peneliti akan melakukan tes tertulis. Sedangkan untuk instrumen non tes, penulis menggunakan angket. Sutedi (2011, hlm. 155) mengemukakan bahwa instrumen pendidikan yaitu alat yang digunakan untuk mengumpulkan atau menyediakan berbagai data yang diperlukan dalam kegiatan penelitian. Dalam penelitian pendidikan, instrumen penelitian secara garis besar dapat digolongkan menjadi dua, yaitu berupa tes dan non tes. Instrumen yang berupa tes terdiri atas tes tulisan, tes lisan, dan tes tindakan. Instrumen non tes dapat berupa angket, pedoman observasi, pedoman wawancara, skala sosiometri, daftar dan lain sebagainya (Sutedi, 2011, hlm. 156). Dalam penelitian ini data diambil dari kedua instrumen penelitian yaitu tes dan non tes. Untuk instrumen penelitian berupa tes, peneliti akan melakukan tes tertulis. Sedangkan untuk instrumen non tes, penulis menggunakan angket.

Hasil angket dianalisis dengan cara mencari presentase masing-masing pernyataan untuk setiap pilihan jawaban, yaitu dengan menggunakan rumus:

$$
\mathrm{P}=\frac{f}{N} \times 100 \%
$$

Keterangan:

$\mathrm{P}=$ angka presentase

$\mathrm{F}=$ frekuensi jawaban

$\mathrm{N}=$ banyaknya responden

Penafsiran Data Angket

\begin{tabular}{|c|c|}
\hline Interval Presentase & Keterangan \\
\hline $0 \%$ & Tidak ada seorangpun \\
\hline $1 \%-5 \%$ & Hampir tidak ada \\
\hline $6 \%-25 \%$ & Sebagian kecil \\
\hline $26 \%-49 \%$ & Hampi setengahnya \\
\hline $50 \%$ & Setengahnya \\
\hline
\end{tabular}




\begin{tabular}{|c|c|}
\hline $51 \%-75 \%$ & Lebih dari setengahnya \\
\hline $76 \%-95$ & Sebagian besar \\
\hline $96 \%-99 \%$ & Hampir seluruhnya \\
\hline $100 \%$ & Seluruhnya \\
\hline
\end{tabular}

(Arikunto, 2006, hlm 263)

Teknik pengolahan data yang digunakan dalam penelitian ini adalah teknik analisis regresi digunakan untuk mengetahui, penggunaan strategi membaca selektif memberikan kontribusi terhadap pemahaman membaca teks Bahasa jepang (dokkai). Persamaan regresi yang diperoleh berfungsi memprediksi sumbangan variabel bebas strategi membaca selektif) terhadap variabel terikat (pemahaman membaca teks dokkai).

Untuk mengetahui persamaan regresi dilakukan perhitungan dengan rumus :

$$
\mathrm{Y}=\mathrm{a}+\mathrm{bX}
$$

Keterangan :

$\mathrm{Y}=$ variabel terikat yang diprediksi

$\mathrm{X}=$ variabel bebas yang mempengaruhi

$\mathrm{a}=$ harga $\mathrm{Y}$ bila $\mathrm{X}=0$

$\mathrm{b}=$ arah koefisien regresi yang menunjukan peningkatan atau pengurangan variabel terikat $(\mathrm{Y})$ akibat dari pengaruh dari variabel bebas $(\mathrm{X})$.

Untuk mengetahui nilai a dan $b$, dilakukan perhitungan menggunakan rumus :

$$
\mathrm{a}=\frac{\left(\sum x^{2}\right)\left(\sum y\right)-\left(\sum x\right)\left(\sum x y\right)}{N \sum x^{2}-\left(\sum x\right)^{2}}
$$

Untuk mencari nilai $b$, digunakan rumus :

$$
\mathrm{b}=\frac{N \sum X Y-\left(\sum X\right)\left(\sum Y\right)}{N \sum x^{2}-\left(\sum x\right)^{2}}
$$

Kemudian untuk mengetahui apakah variabel $X$ (penggunaan strategi membaca selektif) merupakan predikator bagi variabel Y (kemampuan pemahaman membaca 
teks pendek Bahasa Jepang), maka dilakukan pengujian arah regresi. Adapun prosedur pengujiannya adalah sebagai berikut :
a) $\mathrm{S}^{2} \mathrm{YX}=\frac{\sum(Y-Y)^{2}}{n-2}$
b) $\mathrm{S}^{2} \mathrm{~b}=\frac{\mathrm{s}^{2} \mathrm{YX}}{\sum x^{2}-\frac{\left(\sum x\right)^{2}}{N}}$
c) $\mathrm{Sb}=\sqrt{s^{2} b}$
d) $\mathrm{t}=\frac{b}{S b}$

Teknik analisis korelasi digunakan untuk mengetahui, seberapa besar hubungan antara strategi membaca selektif dengan pemahaman membaca teks Bahasa jepang (dokkai).

Teknik analisis korelasi ini menggunakan korelasi product moment dengan rumus :

$$
r_{x y}=\frac{N \sum X Y\left(\sum X\right)\left(\sum Y\right)}{\sqrt{\left\{N \sum X^{2}-\left(\sum X\right)^{2}\right\}\left\{N \sum Y^{2}-\left(\sum Y\right)^{2}\right\}}}
$$

Keterangan:

$r_{x y}:$ Koefisien validitas

$\mathrm{N}$ : Banyaknya subjek

$X$ : Nilai pembanding

Y : Nilai dari instrument yang akan dicari validitasnya.

\section{HASIL DAN PEMBAHASAN}

Berdasarkan uraian yang telah diungkapkan sebelumnya bahwa hipotesis dalam penelitian ini adalah terdapat hubungan yang signifikan antara strategi membaca terhadap kemampuan pemahaman teks dokkai pada mahasiswa tingkat II Departemen Pendidikan Bahasa Jepang UPI tahun ajaran akademik 2014/2015. Dari hasil pengolahan data yang telah dilakukan dapat diketahui bahwa hampir 
sebagian besar responden mengetahui tujuan dalam membaca teks dokkai dan mengetahui informasi tentang strategi membaca. Dapat diketahui pula hampir semua responden menggunakan strategi membaca untuk mempermudah membaca, kebanyakan strategi membaca selektif, membaca ulang bagian teks yang belum dipahami, menerjemahkan setiap kata yang ada di dalam teks ke dalam Bahasa Indonesia dan memberi huruf furigana pada kanji-kanji yang belum diketahui merupakan strategi yang paling sering diterapkan oleh para responden. Dari hasil analisi data tes pemahaman membaca diketahui bahwa nilai rata-rata yang diperoleh sebesar 70,1 dan dapat disimpulkan bahwa kemampuan membaca pemahaman teks dokkai mahasiswa tingkat II Departemen Bahasa Jepang UPI dapat dikategorikan ke dalam kategori kurang dan dari hasil tersebut dapat disimpulkan bahwa strategi membaca memiliki pengaruh yang cukup terhadap kemampuan pemahaman membaca.

\section{KESIMPULAN}

1. Berdasarkan dari analisis data di atas, Sebagian besar mahasiswa kelas 3A tingkat II angkatan 2014/2015 mengetahui adanya strategi-strategi untuk mempermudah mahasiswa dalam membaca pemahaman teks dokkai. Dari hasil angket dapat diketahui bahwa sebagian besar mahasiswa kelas 3A memperoleh informasi tentang strategi membaca dari buku yang pernah mereka baca. Sebagian besar dari responden menggunakan strategi-strategi membaca tertentu dan menggunakan strategi membaca selektif. Kemampuan membaca pemahaman mahasiswa tingkat II Departemen Pendidikan Bahasa Jepang UPI tahun ajaran 2014/2015 termasuk ke dalam kategori kurang. Hal ini dibuktikan berdasarkan perhitungan tes yang telah di berikan dan menghasilkan nilai rata-rata 70,1. Terdapat hubungan yang signifikan antara penggunaan strategi membaca selektif terhadap kemampuan membaca teks dokkai

\section{REFERENSI}

Brown, D.B. \& Hudson, T. (2002). Criterion-Referenced Language Testing. Cambridge: Cambridge University Press.

Margono, Drs. S. Margono. (2004). Metodelogi

Sutedi, Dedi. (2011). Penelitian Pendidikan Bahasa Jepang. Bandung : Humaniora. 
JAPANEDU, Vol. 1, No. 1, April 2016 
読解能力と読書選択的の方法の相関関係

（2014. 2015 年度言語文学学部インドネシア教育大学日本語教育学科の第二年生に 対するデスクリプト定量的な研究)

\title{
Adhistiara Amalia Ananda Drs.Ahmad Dahidi, M.A.,' Juju Juangsih,M.Pd. ${ }^{2}$
}

\section{Departemen Pendidikan Bahasa Jepang Fakultas Pendidikan Bahasa dan Sastra Universitas Pendidikan Indonesia Ayaryu707@yahoo.com}

\author{
日本語教育学科 \\ 言語文芸教育学部 \\ インドネシア教育大学
}

\begin{abstract}
要旨
日本語の学習者にとって日本語の記事を読むのは必要だと言われている。なぜなら日本語の 記事を読むと知識が増すだけではなく、言語の能力を上げることもできる。日本語を学習し ていると様々な能力を学習寸る。その一つは読解である。読解は短い時間に記事を理解する 能力である。短い時間に記事を理解寸るため動力やストラテジーが必要である。この研究の 目的は、学習者における読解力と読書選択的の方法の相関関係と読解能力を明らかにする。 読解能力と読書選択的の方法は相関関係であるか、ないかを研究する。この研究は、記述法 を用いている。データを収集するための方法はテスト、そしてアンケートである。この研究 は、2014、2015 年度のインドネシア教育大学日本語教育学科の二回生 20 名を対象とする。 データの結果から、相関点は 0,91 であり、読解能力と選定的読書方法は比較的良く、読書力 は 82\%の影響をうけることが分かった。このことから、2014、2015 年度のインドネシア教育 大学日本語教育学科の二回生 20 名のテストおよび、アンケートの結果から読解能力は、読解 力と比例する関係にあるという仮説が成り立つ。
\end{abstract}

キーワード : 読書選択的の方法、読解能力、相関関係

\footnotetext{
${ }^{1}$ Penanggung Jawab 1

${ }^{2}$ Penanggung Jawab 2
} 


\section{A. はじめに}

日本語の学習で学べる能力があり、それは読解、聴解、会話、と作文である。 その能力を初級から上級の日本語学者へ熟練しなければならない。日本語の学 習者にとして日本語の記事を読むのは必要だと言われている。日本語の記事を 読むと知識を増すだけではなく言語の能力を上げることもできる。日本語を学 習していると様々能力を学習し、その一つは読解である。読解は短い時間に記 事を理解する能力である。短い時間に記事を理解するため動力やストラテジー 必要である。ほぼ日本語学者は読解の手腕で読書の意味を表せない。

このことも読解の授業によく行っている。なぜかと言うといくつかの原因が ある。例えば、読んでいる読書の意味を分かるため学者その読書のテーマを表 せないといけない。せめてテーマや読書のコンセプトの基本的な知識を分かる ベきである。

読書の方法について、brown (読書の方法は読者によるの読解の能力を上げる ための方法である) 基本的には学者の読む策略が読書に於けて情報を手に入れ る事を表せる。読む策略を持っている学生は読書を正しく読む欲求が高い。し たがって、その欲求がある限りがくせいが読書を優しく分かって、熟練して、 さらに読解の能力も達する。

\section{B. 研究の目的}

本研究の目的は以下のようである。

1. 学生による読書選択的の方法使用の一般的な説明を知るためであり、特に読 書選択的の方法使用方策である。

2. 読解テキストを理解するにおけるインドネシア教育大学の日本語の教育学 科の 2 年生の量を記述するためである。

3. 読解の短いテキストと読書選択的の方法の使用に関係を知るためである。 


\section{C. 研究の方法}

テストは一つの種類でがある。第一課は 45 分の限り、読解能力のテストで ある。次は 5 分過ぎないでアンケートをやることにした。その後、収集された データを統計的で処理、分析、それに解決する。次のような数式でテストのデ ータを下のような分析になった。

\section{D. 研究の用具}

データを集めるためにテストを行う。テストは読書選択的の方法を計算する ためアンケートを行う。アンケートは 25 問である。読解能力を計算するため、 テストを行うテストは 25 問である。

\section{E. データ分析および議論}

1. データ収集のテクニック 本研究データ収集のテクニックは以下のようである。

a) 読解と読書選択的の方法の理論根拠を知るために文献調査を行う。

b) 2014-2015 年度のインドネシア教育大学日本語教育学科の二年生の学習 者の読解能力と読書選択的の方法を知るために、テストとアンケートを 使用する。テストは 2015 年 11 月 5 日の木曜日に言語美術教育学部のビ ルでおこなった。

2. データ分析

本研究は、記述法を用い、定量的を使用である。Sutedi (2011, hlm.58) によると、「記述法とは現代に発生状態を説明するために科学的な手続きを用 い行う研究である」と書いておる。

この記述法の研究には決定、選択、問題をまとめ、データの種類と収集 方法を決定、その決定したデータを解析、解決を引き出すという研究手順です 
る。その後、収集されたデータを統計的で処理、分析、それに解決する。次の ような数式でテストのデータを下のような分析になった。

1. 相関関係の解析

> 係数の相関関係を計るための数式

$$
\mathrm{r}_{\mathrm{xy}}=\frac{\mathrm{N} \Sigma \mathrm{XY}-(\Sigma \mathrm{X})(\Sigma \mathrm{Y})}{\sqrt{\left[\mathrm{N} \Sigma \mathrm{X}^{2}-(\Sigma \mathrm{X})^{2}\right]\left[\mathrm{N} \Sigma \mathrm{Y}^{2}-(\Sigma \mathrm{Y})^{2}\right]}}
$$

$>\mathrm{t}$ を計るための数式

$$
\mathrm{t}=\frac{\mathrm{r} \sqrt{\mathrm{n}-2}}{\sqrt{1-\mathrm{r}^{2}}}
$$

$\mathrm{t}_{\text {点 }>\mathbf{t} \text { tabel }}$ の場合、係数の相関関係は有意なだということである。 $\mathrm{t}_{\text {点 }} \mathbf{t}_{\text {tabel }}$ の場合、係数の相関関係は、逆に有意なではなくなる。

$>「$ Koefisien determinan」を計るための数式

2.「Regresi」の解析 $\quad r^{2} \times 100 \%$

> 下のような数式で「regresi」の方程式を決定する:

$$
\mathrm{Y}=\mathrm{a}+\mathrm{bX}
$$

備考: $\mathrm{Y}=$ 従属変数

$$
\begin{aligned}
& \mathrm{X}=\text { 独立変数を影響受ける } \\
& \mathrm{X}=\mathrm{O} \text { にならば、 } \mathrm{a} \text { は } \mathrm{Y} \text { とイコール } \\
& \mathrm{b}=\mathrm{X} \text { の影響で与えられた } \mathrm{Y} \text { の増減を表す「regresi」の } \\
& \text { 係数 }
\end{aligned}
$$


次には、アンケートのデータ を解析ための段階は、下のように進めて いくなる。

1. 各回答及び回答のナンバーを表に揃える。

2. ひとつずつの各質問及び回答された質問を分析し、記述する。筆者 は下のような数式を使用した。

$$
\mathrm{P}=\frac{\mathrm{f}}{\mathrm{n}} \times 100 \%
$$

備考:

$$
\begin{aligned}
& \mathrm{P}=\text { パセント } \\
& \mathrm{f}=\text { 周波数誤差 } \\
& \mathrm{n}=\text { 応答者数 }
\end{aligned}
$$

3.それから、結果率はアンケートの解釈に即する。

$$
\text { アンケートの解釈 }
$$

\begin{tabular}{|c|c|}
\hline パーセンテージの間隔 & 解釈 \\
\hline $0 \%$ & いない \\
\hline $1 \%-5 \%$ & 少々 \\
\hline $6 \%-25 \%$ & 小分数 \\
\hline $26 \%-49 \%$ & 半部以下 \\
\hline $50 \%$ & 半分 \\
\hline $51 \%-75 \%$ & 半部以上 \\
\hline
\end{tabular}




\begin{tabular}{|c|c|}
\hline $76 \%-95$ & 大体 \\
\hline $96 \%-99 \%$ & ほとんど \\
\hline $100 \%$ & 全部 \\
\hline
\end{tabular}

(Arikunto, 2006: 263)

\section{F. 議論}

次に、データ分析の結果を述べる。データ分析の結果は以下ような段階で進め ていく:

1. 半分以上の 3A クラスの二年生の 2014. 2015 年度の学生が簡単に読解 のテキストを読んで理解するために様々なストラテジーがあるのがして いる。アンケートの調査結果によると半分以上の $3 \mathrm{~A}$ クラスは読書のス トラテジーの情報は読んだことある。本がしている。半分以上の回答者 は読書選択的の方法使っている。

2. 分析の結果によると、平均点の読解能力テストは 7,0 1 を得る。学習者 の読解能力の平均点は足りないの分類されていた。

3. 読解能力と読書選択的の方法の間に強い範疇を係数の相関関係点は 0,91 で表し、それに文型能力及び読解能力の他の変数からの貢献は $82 \%$ 及 び $18 \%$ である。それによって、有意なの相関関係を見られる。 


\section{参考文献}

Arikunto S, 2006. Prosedur Penelitian Suatu Pendekatan Praktik, Ed Revisi VI, Penerbit PT Rineka Cipta, Jakarta.

Brown, D.B. \& Hudson, T. (2002). Criterion-Referenced Language Testing. Cambridge: Cambridge University Press.

Sutedi, Dedi. 2011. Penelitian Pendidikan dan Bahasa Jepang. Bandung: Humaniora. 